\title{
The Application of Career Theories in Teachers' Professional Development and Career Decision: A Literature Review
}

\author{
Ching Ting Tany Kwee \\ School of Education, Faculty of Arts and Social Science, University of New South Wales, Sydney, Australia
}

Received May 20, 2020; Revised July 4, 2020; Accepted July 20, 2020

\section{Cite This Paper in the following Citation Styles}

(a): [1] Ching Ting Tany Kwee, "The Application of Career Theories in Teachers' Professional Development and Career Decision: A Literature Review," Universal Journal of Educational Research, Vol. 8, No. 9, pp. 3997 - 4008, 2020. DOI: 10.13189/ujer.2020.080925.

(b): Ching Ting Tany Kwee (2020). The Application of Career Theories in Teachers' Professional Development and Career Decision: A Literature Review. Universal Journal of Educational Research, 8(9), 3997 - 4008. DOI: 10.13189/ujer.2020.080925.

Copyright $(2020$ by authors, all rights reserved. Authors agree that this article remains permanently open access under the terms of the Creative Commons Attribution License 4.0 International License

\begin{abstract}
This literature review aims at exploring two career theories, one career model, and their applications to facilitate the comparison of their advantages and shortcomings in understanding contextual and personal factors influencing teachers' career choices. It first examines the chosen career theories and models in teachers' professional development, namely, Fuller's Concern Stage Theory, Fessler's Eight-stage Teacher Career Cycle Model The Social Cognitive Career Theory. Common factors encapsulated by those theories are outlined, and a close examination of how those theories prioritize contextual and personal factors are also discussed. This literature review also highlights some current research gaps of examining teachers' their career choices: an ambiguous interplay between personal and environmental factors, an ambivalent attitude towards considering psychological factors, neglecting in-service teachers in late-career development and exit stage, inadequate synchronic and diachronic studies on contextual and personal factors, and a weak association between influencing factors, teachers' sense of identity and their career choices. Through a discussion of those teachers' career theories, models and their applications, this literature review probes into the importance of examining the interplay between personal and environmental factors in order to understand how and why experienced teachers become demotivated and frustrated in different career stages. It also provides a more holistic
\end{abstract}

view and insight on retaining experienced in-service teachers and alleviating the global teacher attrition and shortage problem.

Keywords Career Theory, Teachers' Professional Development, Teachers' Career Development, Social Cognitive Career Theory, Concern Theory, Stage Theory

\section{Introduction}

Teacher shortage has become an alarming global issue [1-5]. Undoubtedly, many researchers [6-9] endeavoured effort in an attempt to alleviate such a problem by understanding more on teachers' professional development and career decision. Research studies were done in hopes of identifying factors influencing teachers' professional development and career choices. A hurdle that researchers have been facing is that teachers were coming from diverse backgrounds, particularly countries like Australia, the United Kingdom, and the United States [1-10].

Currently, research studies $[11,12]$ on teachers' professional development and career choices showed some limitations in alleviating the shortage problems. Researchers [13-16] oversimplified factors or reached one-size-fits-all solutions too quickly. Some researchers 
$[7,9,17]$ acknowledged teachers' background and previous experiences impact their professional development and career choices; however, they focused more on pre-service and early-career teachers rather than in-service highly competent experienced ones. Some researchers $[18,19]$ identified factors influencing teachers' different professional development in different stages but did not address how factors synchronically and diachronically influence teachers' career decisions of entering or exiting their teaching career in relation to their sense of identity. In fact, teachers' backgrounds and prior experiences comprise a broad spectrum of factors and elements, which include personal, cognitive and contextual factors [20]. Interestingly, these factors, to different extends, influence their perception of success or failure in their teaching career, as well as their motivation, satisfaction, a steady commitment to teaching, goals or chances at their different professional development stages [19], and hence influence teachers' decision moving in or out their teaching career $[20,21]$.

\subsection{Purpose of the Study}

The purpose of this study is to explore two career theories and one model and how they are applied to teachers' professional development and career decisions. First, it will point out how those theories and models depict teachers' professional development stages or cycles. Second, it will encapsulate some common factors pointed out by different theories which influence teachers' career choices at different professional development stages. Third, it will examine to what extend teachers' personal factors are taken into consideration in their professional development and career choices in those theories and models. Finally, it will highlight some current research gaps on the inadequate explorations on experienced in-service teachers' mid-career change of leaving a teaching career as previous researches mainly focus on one status group of teachers, namely pre-service teachers.

The following parts will examine Fuller's Concern Stage Theory [22,23], Fessler's Eight-stage Teacher Career Cycle Model [24,25], and the Social Cognitive Career Theory [26,27]. These theories and models are chosen because of their significance and substantial impacts on later development and perception of teachers' professional development models [28]. First, the checklist developed based on Fuller's Concern Stage Theory is still applicable and used in current research studies [29]. There has also been a continuous effort in modifying the theory to overcome its shortcomings [30]. Another reason for choosing these theories and models is that these theories and models have incorporated various psychological or adult growth theories into teachers' professional development. Fessler's Eigh-stage Teacher Career Cycle Model adopts a social system approach and gives a historical perspective to life-cycle research. Similar categorization of teachers' career stages can be seen in works from Huberman, Skes and Day [31,32]. As for the Social Cognitive Career Theory, it adopts a constructivist approach and embraces career and psychological counselling into the theory to highlight humans can actively influence their development and surroundings $[27,33]$. Examining these theories and models can provide a holistic perspective on how teachers' career theories develop diachronically. Thirdly, these theories demonstrate different priorities when examining teachers' career choices with respect to personal and contextual factors. This can facilitate a comparison between the advantages and shortcomings of each theory and model to give a better idea of understanding individual teachers' career decision process in the similar educational or social setting.

\section{Fuller' s Concern Stage Theory}

Fuller's classic Concern Stage Theory [22] gives an understanding of the progression of beginning teachers' concerns in their different career stages and has persisted unchanged to the present time [34]. These phases of concerns are sequential and accumulative [22]. This theory attempts to explain the perceptions, anxieties, problems, frustrations, and satisfactions teachers experience as they progress through a teacher education program. Earlier Fuller [22] dichotomized data of various studies and categorized concerns into concerns about self and principal concerns which are related to students. According to Fuller (1970), there are three stages of concerns - Concern about Self, Concern about Teaching Task, and Concern about Impact. Concerns can be generally defined as the perceived problems of teachers [22]. To put it short, it is something teachers think about frequently and would like to do something personally [35].

\subsection{Concern about Self}

The first stage of teaching is Concern about Self [22,23]. Fuller [36] indicated that compared to their teaching career, teachers are more concerned about their own feelings and personal problems. Such inclination is due to a lack of knowledge about both the teaching and education realm. Even though teachers may have reported some concerns about their teaching, those concerns are generally amorphous and vague as most of those teachers do not know what to be concerned about [22]. Fuller [36] positively addressed such concerns as expected, accepted, and normal part of everyone's experiences.

\subsection{Concern about Teaching Task}

The second stage is Concern about Teaching Task $[22,23]$. At this stage, teachers are more concerned about 
what students have learnt and their success in the classroom and their satisfaction and gains [36]. When teachers first enter a teaching career, they are more concerned about how to look smart and well-prepared in front of their students so as to control them better and answer their questions more confidently [36]. Teachers at this stage are also becoming more concerned about effective methods and instructional designs of lessons to boost their teaching effectiveness [36]. They may try to estimate how much support they can receive from the school principal or supervisors and how to build working relationships with school personnel [22]. Fuller [36] suggested that teachers' concern about their teaching tasks is out of personal concerns as the effectiveness of teaching directly affects how students perceive them. As for this aspect, Fuller [22,36] addressed vocally that such concerns are "survival concerns" and they are still not mature concerns. Nevertheless, teachers at this stage are ready for some teaching-related content but not methods of evaluating students' gain.

\subsection{Concern about Impact}

The third stage is Concern about Impact [22,23]. Fuller [36] highlighted that such concerns are more mature than the previous ones. Teachers at this stage have become concerned about students' gain and their influence on such gain. They also reflect on their previous teaching experience to see how their teaching can be done better, such as guiding, challenging, and meeting the diverse needs of students [36,37]. However, Fuller [36] also suggested that such concerns are rare and not common among novice teachers.

The development pattern of concerns can be summarised as a general movement from inward to outward (Fuller, 1970). Fuller [36] suggested teachers' concerns occur in a fairly regular sequence from an early concern about oneself to later concern about students, and they tend not to appear simultaneously. It also fits the normative expectation that teachers' ultimate concern ought to be about students and student learning rather than self or situations [38].

\subsection{Application of Concern Stage Theory in Teachers' Professional Development}

One interesting finding of the application of Concern Stage Theory is that Fuller [22] pointed out that teachers who retained in their early concerns about self are more likely to leave their teaching career. However, later researchers $[39,40]$ pointed out that even though there was a decrease in the survival concerns and an increase in concerns about teaching tasks, but the teachers' concerns about their impact remained stable between pre-service and in-service teachers.

Nevertheless, Concern Stage Theory has remained highly influential and was adopted by various researchers in fields related teachers' professional development, ranging from early career and pre-service teacher training [36], teaching methodologies of subject teachers [41,42], different educational reforms, and integration of groups of students with special educational needs [38]. The model has also been found useful in teacher preparation and professional development by addressing their needs and concerns according to a trajectory of professional development [41]. Some researchers [34] pointed out that after years this conceptualization has persisted unchanged to the present time because practically, many teachers have noticed a similar progression of concerns in their professional development [38].

\section{Fessler's Eight-stage Teacher Career Cycle Model}

Fuller's Concern Stage Theory [25] consists of a shortcoming that it neglects how mature teachers continue to grow and develop. Some researchers [30] suggested there is a need to extend the theory. Inspired by the Chicago school's developmental psychology, consideration of the social system and social psychological perspectives is incorporated [31]. Fessler [24,25] proposed Eight-stage Teacher Career Cycle Model in an attempt to conceptualize a teacher's career cycle within the context of a dynamic and flexible social system.

Unlike Fuller's model [22,23], Fessler's Eight-stage Teacher Career Cycle Model [24] stresses that progression through stages is not in irreversible lockstep, linear fashion. Nevertheless, Fessler [25] still recognized the regularity on the course of changes by specific problems, preoccupations, and attitudes towards job and learning activities.

According to Fessler [24], teachers move through those developmental stages not necessarily in a pre-determined trajectory or predictable chronological sequence. Instead, it is a dynamic manner reflecting responses to personal and organizational environmental factors [43]. This model makes such a dynamic manner possible because it has incorporated theories in social psychology, human development, and management [44,45]. It illustrates how development proceeds through the interplay and resolution of conflicts between the needs of individual teachers and the demands of the organization $[25,44]$.

\subsection{The Eight Stages in Teacher Career Cycle}

Fessler's model [24,25] outlined an eight-stage teacher career cycle model: pre-service, induction, competency building, enthusiastic \& growing, career frustration, career stability, career wind-down, and career exit. 


\subsubsection{Preservice}

This phrase is the beginning period of preparation for a specific professional role, including an initial study in a college or university $[24,46]$. Apart from initial teacher training, it also involves retraining for a new professional role $[46,47]$.

\subsubsection{Induction}

In the first few years of service, a teacher strives to adapt to this role and be accepted by the social surrounding [47]. Teachers at this stage started to socialize into the professional and social fabric of the school and community. They have developed some strategies recommended by their colleagues to be in sync with the more traditional teaching practices [46].

\subsubsection{Competency Building}

Teachers at this stage have been socialized in the system and become highly motivated to participate in professional development programmes [24,47]. They want to acquire more work-related knowledge, develop work-related skills, and become more acquainted with different teaching materials [47]. Fessler [25] perceived this stage as a crossroad - if teachers succeed in these attempts will enter the Enthusiasm and Growing stage, while failure will lead to Career Frustration.

\subsubsection{Enthusiasm and Growth}

Teachers at this stage have reached a high level of competence in their jobs and continue to progress as professionals [25]. They demonstrate a positive affective attitude: they love their jobs, look forward to going to school, to being involved in school activities and classwork, and to interacting with their students [25,47]. They are constantly seeking new ways to enrich their teaching and to contribute more to the institution where they are employed [24,46,47]. Some of them are more willing to be served as peer coaches, and their excitement about learning new things and their commitment to the profession can be influencing and rippling among the other workmates [45].

\subsubsection{Career Frustration}

Frustration and disillusionment with teaching characterize this career stage [25]. At this stage, teachers demonstrate negative affective attitude: they are lack of job satisfaction and may question their choice of entering the teaching profession [24,46,47]. Another significant indicator is that teachers at those stages show some symptoms of burnout, and start feeling emotionally exhausted and depersonalized [47]. As mentioned earlier, Fessler [25] correlates such career frustration to failure to adapt to a professional role and with an unfavourable environment.

\subsubsection{Career Stability}

At this stage, teachers are neither highly motivated nor demotivated. Stability may be created due to a lack of flow in professional development [47]. Teachers at this stage are generally lack of great enthusiasm in pursuit of excellence, innovation, and growth. [44,47]. They are merely moderately motivated to perform work activities and complete what is expected of them $[64,67]$.

\subsubsection{Career Wind-down}

This stage is like a period of preparation for retirement or a career change [24]. According to Fessler [25], this period can be either pleasant or unpleasant. Teachers at this stage may reflect on many positive experiences they had and look forward to a career change or retirement [46]. In contrast, some teachers at this stage may have ambivalent feelings and emotions, which leads to a career termination [46].

\subsubsection{Career Exit}

At this stage, teachers may leave their profession voluntarily or involuntarily; temporarily or permanently [25]. This kind of career exit may happen due to a number of reasons, for example, for another job, for personal or family reasons [47]. This career stage may also be a time of alternative career exploration or of moving to a non-teaching position $[24,46]$.

\subsection{Application of Fessler's Eight-stage Career Cycle Model}

There have been some research studies examining teachers' career development characteristics in general and special schools in different countries by adopting this stage model [31,47]. Various personal factors related to career choices like emotions, gender, age and family duties have been identified in various researches $[47,48]$. Moreover, an understanding of career stages has also become more crucial in teacher leadership as it suggested teachers in particular stage to take up more responsibilities like being role models or mentors at schools [45]. In the scope of school leadership, some researchers [44] extended beyond the professional development of teachers to principals' career life stages to understand how principalship develops in terms of time perspectives and environmental influences.

Based on the observation of Fuller's Concern Stage Theory $[22,23,36]$ and Fessler's Eight-stage Career Cycle Model [24,25], although there is no consensus on the number of teachers' professional development stages, mostly teacher professional development is related to changes in teachers' experience in (1) job skills, knowledge, and behaviours; (2) attitude and outlooks; and (3) job events [18]. One significant difference between earlier and later models is that the earlier models tend to consider teachers' careers as a progression through stages $[18,19,22]$ while later models tend to incorporate adult growth and development onto teachers' career stages 
$[24,49]$. In short, professional development is a life-long project which promotes changes in a teacher's knowledge base and actions through sets of activities designed to promote personal, professional change [4]. Fuller's Concern Stage Theory $[22,23,36]$ and Fessler's Eight-stage Teacher Career Cycle Model [24,25] have brought insight on understanding how personal and contextual factors were identified in earlier and later stage model theories.

\section{The Social Cognitive Career Theory}

Fessler [24,25] has identified personalized support systems for teachers at various stages; however, no special attention has been paid on how and why teachers make an effort to transit to different career stages. With a growing interest and research development in career assessment, development, and counselling, popular topics like cognition, personal agency, and empowerment are incorporated to look into an individual's ability to make changes [26,27,50]. Adopting constructivist assumptions, the Social Cognitive Career Theory examines how humans make changes in themselves and their environment as an active free decision-making agent $[26,51]$.

The Social Cognitive Career Theory (SCCT) is a career-oriented theory, designed to explore the career decision, employment, and turnover problems [26,27,51-53]. The SCCT focuses on the interaction between three components: teachers' self-efficacy, outcome expectations, personal goals and career development [26] and describes career development and decisions through scaffolding the complex relationships between personal influence, contextual influences, and behaviours [51,52]. The SCCT also includes constructs that allow the possibility of changing by predicting relationships among interest, outcomes expectations, intentions to enter a career, and self-efficacy $[9,26,51]$.

\subsection{An Overview of the Social Cognitive Career Theory}

Based on Bandura's Social Cognitive Theory [54], researchers [26] developed the SCCT to understand how personal, cognitive and contextual factors influence career and academic choices. It aims to examine how career and academic interests mature, how career choices are developed, and how these choices are turned into action and persist [55]. The SCCT describes career development and decisions by scaffolding the complex relationships between personal influence, contextual influences, and behaviours. These behaviours include the growth of academic interests, career choices, and level of performance [27]. It focuses on the interaction of the variables of self-efficacy, outcome expectations, and personal goals in relation to career behaviours [26].

\subsection{SCCT Constructs}

Although there are many SCCT constructs related to a career choice, such as decision-making process, interests, and contextual experiences, this part of the literature review focuses on self-efficacy. Self-efficacy is of utmost importance to understand how a person would project the anticipated outcomes based on his beliefs and personal experience, and how much the anticipated outcomes can dynamically influence one's career decision of retaining or leaving his profession [56]. Outcome expectations and personal goals will also be briefly addressed to provide a fundamental understanding of the SCCT.

\subsubsection{Self-efficacy}

The concept of self-efficacy centres on an individual's belief that he or she is capable of completing a task successfully [54]. Self-efficacy beliefs are obtained and modified through four types of learning experiences; (a) enactive attainments, (b) vicarious experiences, (c) verbal persuasion, and (d) physiological states [54]. In a career decision-making process, self-efficacy is important while personal accomplishments are seen as the strongest influence on self-efficacy $[33,34]$. A person experiencing low self-efficacy tends to avoid academic majors and careers related to the area of low self-efficacy and vice versa.

\subsubsection{Outcome Expectations}

Outcome expectations are what an individual thinks will happen as a result of personal actions [57]. Researchers [33] suggested that self-efficacy expectations are behaviorally specific. Personal beliefs influence one's engagement in some particular behaviours [36-38]. Hence, self-efficacy beliefs can be self-aiding or self-hindering [61]. Within the context of SCCT, the academic and career self-efficacy of clients are accessed [62]. For instance, anxiety induced by fear of poor performance can lead to a self-fulfilling prophecy - such fear is realized due to his subsequent decline in self-efficacy beliefs $[31,41,42]$.

Combining self-efficacy as a belief in ones' capability to overcome a specific barrier by investing effort and strategies [28,29], it can understand better how self-efficacy and outcome expectations reciprocally together shape one's career interests and to influence one's career goals, choice, and performance both directly and indirectly via their relationship with career interests [26].

\subsubsection{Personal Goals}

Personal goals are the intentions an individual has to complete a specific act or to achieve at a certain level [57]. Bandura [65] posited that one's personal goals are affected by one's self-efficacy and outcome expectations. He argued that a person's level of enactive attainments, whether weak or strong, informs his or her sense of 
self-efficacy [54]. The strength of one's self-efficacy, or the person's self-confidence in his or her capability, is believed to influence their persistence in that behaviour [66].

When Bandura [22,31] first posited a "triadic reciprocal model", he suggested personal attributes, environmental factors, and overt behaviors are all influenced by each other to a different degree depending on the situation. Combining self-efficacy, outcome expectations and personal goals, it gives direction to self-fulfilling behaviours and helps people to persist in their efforts [52].

In short, based on the nature of scaffolding the dynamic interplay between personal and contextual factors, SCCT explains the interaction between career choices with self-efficacy, which finally results in achievement and brings the additional self-efficacy development of an individual [54].

\subsection{Application of the Social Cognitive Career Theory in Teachers' Career Choices}

The Social Cognitive Career Theory has been widely used in understanding how personal and contextual factors influence teachers' beliefs in relation to their professional development and decision making, in particular, how teachers' mid-career changes. It was used in investigating factors influencing international school teachers leaving or staying in a teaching career in different countries like Taiwan and Fiji $[45,46]$. There were also a few attempts in applying the SCCT in teachers' professional development process from the development of interests to selections and development of career choices [68,69]. Some solutions on teachers' work-family conflict like career intervention programmes [70] were generated based on the framework of the SCCT.

Work satisfaction, which is commonly perceived as a factor influencing teachers' professional development and career choices, has been examined in relation to teachers' self-postulation of their abilities and anticipation of a successful or failing outcome based on the cognitive and psychological comprehension of their work condition [71]. Similar research studies $[12,67,72]$ have also been done on how teachers' self-efficacy mediates their career adaptability and career optimism. The SCCT was also used in investigating the relationship between teachers' beliefs, methodologies and classroom activities to be adopted in teaching subjects like languages and entrepreneurship [73,74].

\section{Identification of Relevant Research Gaps}

As mentioned in the previous section, teacher shortage can be a critical issue in many nations [1]-[5]. Many researchers $[67,75,76]$ attempted to understand more about factors related to teachers' professional development to alleviate this problem. Some current research gaps are identified: first, the dynamic interplay between personal and environmental factors was ambiguous. Second, there is an ambivalent attitude towards analyzing the psychological impacts of the contextual factors in teachers' professional development. Third, most researchers [11,77-79] focused on pre-service or early career teachers instead of experienced in-service teachers. Fourth, there are inadequate research studies on examining personal and contextual factors synchronically and diachronically. Finally, there are limited research studies outlining teachers' sense of identity, factors influencing their professional development, and their career choices.

\subsection{An Ambiguous Interplay between Personal and Environmental Factors}

Although Fuller's conceptualization [22,23] has renounced as one of the most influential ones on the work of many teacher educators at present days [80], her model was meant to be relatively invariant, sequential and hierarchical [81]. Some researchers [38,81,82] posited such concern-based stage theory of teacher development as a linear inward and outward journey, which is a pre-designated progression of in a definite sequence, with one stage following the other. It leads to an over-simplification of the realities of teaching, classroom experiences and feelings of teachers [28,78], [83]. To address this shortcoming, some later career models like Fessler's Eight-stage Teacher Career Cycle Model [24,25] depicted teachers' professional development as a dynamic ebb and flow, stressing teachers moving in and out of stages are their responses to environmental influences [25]. Teachers' emotions, like frustration and enthusiasm, were examined in response to their adaptation towards their work environment. However, both earlier and later career stage theories or models did not state explicitly how teachers move in or out each career stage, in particular, how teachers perceive the teaching realities cognitively and psychologically.

It is important to understand how teachers form those concerns based on their self-belief towards their career choices and develop interests and goals in pursuing their teaching career. Teachers are 'beings-in-the-world', and they are consistently facing challenges and responding to environmental factors. Personal or family issues can happen in teachers' different career stages. A reciprocal relationship between personal and contextual factors at each career stage should not be taken for granted as these factors can influence teachers' perception of their professional identity and how they postulate the outcomes in their career choices. Examining the reciprocal relationship between variables can give a better understanding of how and why teachers transit between 
each career stage.

\subsection{Ambivalent Attitude towards Considering Psychological Factors}

There is an ambivalent attitude towards whether psychological factors should be taken into consideration in teachers' career development among different research studies. Some researchers $[67,84,85]$ validated teachers' personal meaning-making and concerns in the context of their personal and cultural backgrounds. Fuller [36] also endorsed the value of personalistic and individualistic elements and incorporated them into teachers' professional development programs. Some researchers $[86,87]$ also paid attention to personal factors like the influence of future-oriented anticipations in relation to hopes and fears in the teacher's career development. Moreover, career motivation is also a concept mentioned while discussing the psychological factors influencing teachers' careers' choices, and they are presented as a myriad of interpretations based in contexts [88]. Some researchers [43,76,89-92] have identified motivation as a key indicator of categorizing teachers' professional development into different stages and addressed motivations are complex and often influenced by external conditions and contexts, for example, socialization and previous experiences. Fluctuation in a teacher's motivation may lead to a theacher's perceiving his failure or success and hence influences his decision on retainment or career change [20,27].

Nevertheless, incorporating personalistic and individualistic elements in analyzing teachers' professional development is not always welcomed. Zeichner and Teitelbaum [93] criticized Fuller's approach $[22,23]$ of addressing teachers' concerns and suggested emphasis should be put on the political rather than on a personalized concerns-based approach to teacher education. For example, some researchers [94-96] suggested psychological factors are merely teachers' considering their own comfort as the most important goal and relevant parties like school administrators and peer support should be identified instead of teachers' personal factors.

\subsection{Neglecting In-service Teachers in Late-career Development and Exit Stages}

Some researchers [2,97] have pointed out that late-career attrition is troublesome but noteworthy; however, very few journals discussed the exit stage of teachers' careers, in particular how teachers terminate their teaching careers and transits to other professions. Currently, most researchers [17,98,99] focused on pre-service teachers, including teachers entering teaching career in their mid-age. It is essential to understand the core values, beliefs, and expectations as pulling factors of pre-service teachers getting into the teaching career in order to cope with the global teacher shortage problem [100]. At the same time, it is equally important to review and reflect both the pulling factors of in-service teachers' retention and the pushing factors of the termination of their teaching profession $[97,101,102]$.

If teaching is a preferred option rather than a forced choice, it is crucial to examine the in-service teachers' barriers and their need for change. While analyzing the factors of teacher retainment, researchers $[94,103]$ tended to summarise into 'stabilizing factors'. Some researchers [104] pointed out the factors of teachers staying in a teaching career in terms of their motivation and social-economic contexts of communities. For example, some researchers [105] focused on how mid-aged teachers or teachers in the baby-boom generation were retained by their retirement package. Stabilizing factors also can lead to teachers' different career decisions. Some experienced teachers have reported that they had a feeling of being trapped after a long-term service [106]. While a lack of alternatives in a stabilizing stage can be a common feature in teachers' choice of career and decisions to stay [97], some researchers [107] also mentioned that experienced teachers with a similar teaching qualification or training background might turn to attrition from the profession of teaching. By analysing the barriers and needs of the in-service teachers, there will be a better understanding of why they move from one career stage to another and eventually lead to a career choice or retaining or leaving a teaching profession [108].

\subsection{Inadequate Synchronic and Diachronic Studies on Contextual and Personal Factors}

Some researchers $[29,30]$ have already pointed out that concerns stated in Fuller's Concern Stage Theory $[22,23]$ are not in a progressive sequence. Some concerns recur in different stages of teachers' career development. Besides, most of the research studies are done on specific groups of teachers at some particular career stages $[38,41,42]$. Hence, longitudinal studies of teachers' concerns related to self, task and impact are necessary to examine how those concerns develop and influence their perception of their teaching career. Such examination is useful in understanding how these concerns develop synchronically and how they work together to influence teachers' career decisions transitting from one stage to another diachronically. Similarly, Fessler [24,25] has incorporated social system approach in the model and identified specific problems, preoccupation, and attitudes towards their career in various professional development stages. However, some personal and contextual factors consistently occur in teachers' lives, leading to fluctuations from entering to exiting a teaching career $[25,47]$.

It is important to examine why some particular factors 
are more likely and plausible in leading certain events in a teaching career [47]. Meanwhile, some longitudinal studies are conducted based on examining specific factors influencing teachers' career paths, for example, years of teaching, geographic locations, age and gender $[82,109]$. Some research studies focused on teachers' performance, particularly on how performance is measured or evaluated in relation to the actions taken in the institutions or schools $[99,110]$. Noticing that teachers' career decisions are a complex web of contextual and personal factors, looking into how the teachers' concerns develop synchronically over time according to changes of the influences of the variables can give a better insight on the relationship between the concerns and teachers' professional development decisions at various professional development stages.

\subsection{Weak Association between Influencing Factors, Teachers' Sense of Identity and Their Career Choices}

Fuller [22,23] suggested that concerns for self, task and impact are not mutually exclusive, and some researchers [38] later extended the theory by "inward and outward" dynamic. However, most research studies adopting Concern Stage Theory were applying it as checklists [29,30,38]. Although elements about teachers' identity like teachers' comfort, students' feedback and challenges in classrooms were mentioned in Fuller's theory [22,23], they were listed as concerns identifying which stages the teachers belong to. Fuller [22,23] mentioned how concerns change in different professional development stages but did not address how these elements would build or diminish a teachers' sense of identity. Teachers' sense of identity can orient their outcome expectations and later lead them to stay or quit a teaching career. Hence, Fuller's theory shows its limitation in understanding the relationship between teachers' identity and career choices. Fessler's Eight-stage Teacher Career Cycle Model [24,25] also shows its limitation in a similar way. Although personal factors like enthusiasm and frustration are included, this theory does not invite researchers to explore further how these factors contribute to teachers' sense of identity and how these factors influence they postulate their success or failure in their upcoming teaching tasks and overall their careers.

Since teacher attrition has become an acute problem, there is a need to develop preparatory measures to address the complexities in affirming teachers' personal goals to get them retained in the industry [1-5]. Both teachers' identity and career choices often comprise an interplay between various professional, situational and personal factors $[77,111]$. They are closely related to variations in teachers' experiences, the realities of teaching and work-life tensions [112]. Examining teachers' sense of identity is necessary as it provides an understanding of their school environment, commitment, goal and teachership in relation to their attainment and integrity $[111,112]$.

\section{Summary}

This literature review first looked at two different career theories, one career cycle model, and their application to understanding teachers' professional development and career decisions. Then it moved to an examination of common factors influencing teachers' career choices. Next, it looked into how personal factors are taken into consideration in different models. Finally, some current research gaps on the career choices and professional development of in-service teachers were addressed. Teachers' professional development is a complex interplay between personal and environmental factors, and there are no one-size-fits-all solutions to teachers' retainment. While teacher shortage has become a global issue [1-3], investigating how highly skilled teachers become demotivated and frustrated can lead to an understanding of how personal and contextual factors influence teachers' postulation of their professional development outcomes. These postulations of failing or successful outcomes can either positively or negatively influence teachers' perception of professional identity, and their sense of identity can lead to retaining or exiting their teaching career. Therefore, an understanding of the interplay of these factors influences their career decisions and can get into the crux of the teacher attrition and retainment problem.

\section{REFERENCES}

[1] L. Sutcher, L. Darling-Hammond, and D. Carver-Thomas, "Understanding Teacher Shortages: An Analysis of Teacher Supply and Demand in The United States," Educational Policy Analysis Archives, 2019, doi: 10.14507/epaa.27.369 6.

[2] E. E. Boe, L. H. Cook, S. A. Bobbitt, and G. Terhanian, "The Shortage of Fully Certified Teachers in Special and General Education," Teacher Education Division of the Council for Exceptional Children, 1998, doi: 10.1177/08884064980210 0103.

[3] R. M. Ingersoll, "Teacher Turnover and Teacher Shortages: An Organizational Analysis," American Educational Research Journal, 2001, doi: 10.3102/00028312038003499.

[4] L. M. Dos Santos, "Recruitment and Retention of International School Teachers in Remote Archipelagic Countries: The Fiji Experience," Education Sciences, Vol. 9, No. 2, p. 132, Jun. 2019, doi: 10.3390/educsci9020132.

[5] L. M. Dos Santos, "Rural Public Health Workforce Training and Development: The Performance of an Undergraduate 
Internship Programme in a Rural Hospital and Healthcare Centre," International Journal of Environmental Research and Public Health, Vol. 16, No. 7, p. 1259, Apr. 2019, doi: 10.3390/ijerph16071259.

[6] R. M. Ingersoll and T. M. Smith, "The Wrong Solution to the Teacher Shortage,” Educational Leadership. 2003.

[7] S. M. Johnson and S. E. Birkeland, "Pursuing a "Sense of Success': New Teachers Explain Their Career Decisions," American Educational Research Journal, Vol. 40, No. 3, pp. 581-617, Jan. 2003, doi: 10.3102/00028312040003581.

[8] S. L. Boblin, S. Ireland, H. Kirkpatrick, and K. Robertson, "Using Stake's Qualitative Case Study Approach to Explore Implementation of Evidence-Based Practice," Qualitative Health Research, Vol. 23, No. 9, pp. 1267-1275, Sep. 2013, doi: $10.1177 / 1049732313502128$.

[9] L. Ingvarson, M. Meiers, and A. Beavis, "Factors affecting the impact of professional development programs on teachers' knowledge, practice, student outcomes \& efficacy," Education Policy Analysis Archives. 2005, doi: 10.14507/epaa.v13n10.2005.

[10] V. Dupriez, B. Delvaux, and S. Lothaire, "Teacher Shortage and Attrition: Why Do They Leave?," British Educational Research Journal, 2016, doi: 10.1002/berj.3193.

[11] L. M. Dos Santos, "Pre-Service Teachers' Professional Development through Four-Step Problem-Solving Model: A Seminar Method," International Journal of Education and Practice, 2019.

[12] L. M. Dos Santos, "International School Science Teachers' Development and Decisions under Social Cognitive Career Theory," Global Journal of Engineering Education, Vol. 22, No. 1, pp. 51-56, 2020.

[13] L. Darling-Hammond, "Research on Teaching and Teacher Education and Its Influences on Policy and Practice," Educational Research, 2016, doi: 10.3102/0013189X16639 597.

[14] K. Leithwood, A. Harris, and D. Hopkins, "Seven Strong Claims about Successful School Leadership," School Leadership and Management, Vol. 28, No. 1, pp. 27-42, Feb. 2008, doi: 10.1080/13632430701800060.

[15] C. B. Hancock, "Music Teachers at Risk for Attrition and Migration," Journal of Research in Music Education, Vol. 56, No. 2, pp. 130-144, Jul. 2008, doi: $10.1177 / 0022429408321635$.

[16] E. A. Hanushek, J. F. Kain, and S. G. Rivkin, "Why Public Schools Lose Teachers," Journal of Human Resources, Vol. 39, No. 2, pp. 326-354, 2004, doi: 10.2307/3559017.

[17] J. M. Gore and K. M. Zeichner, "Action Research and Reflective Teaching in Preservice Teacher Education: A Case Study from the United States," Teaching and Teacher Education, 1991, doi: 10.1016/0742-051X(91)90022-H.

[18] P. R. Burden, "Implications of Teacher Career Development: New Roles for Teachers, Administrators and Professors," Action in Teacher Education, 1982, doi: 10.1080/01626620.1982.10519117.

[19] K. K. Newman, P. R. Burden, and J. H. Applegate, "Helping Teachers Examine Their Long - range Development,"
Teacher Educator, Vol. 15, No. 4, pp. 7-14, Mar. 1980, doi: $10.1080 / 08878738009554738$.

[20] L. M. Dos Santos, “The Relationship between Teachers' Beliefs, Teachers' Behaviors, and Teachers' Professional Development: A Literature Review," International Journal of Education and Practice, Vol. 7, No. 1, pp. 10-18, 2019, doi: 10.18488/journal.61.2019.71.10.18.

[21] R. H. Zabel and M. Kay Zabel, "Revisiting Burnout Among Special Education Teachers: Do Age, Experience, and Preparation Still Matter?," Teacher Education Division of the Council for Exceptional Children, 2001, doi: $10.1177 / 088840640102400207$

[22] F. F. Fuller, "Concerns of Teachers: A Developmental Conceptualization," American Educational Research Journal, 1969, doi: 10.3102/00028312006002207.

[23] F. F. Fuller, "Personalized education for teachers: One application of the Educational Researcher," American Educational Research Journal, Vol. 6, No. 1, pp. 207-226, 1970.

[24] R. Fessler and J. Christensen, The Teacher Career Cycle: Understanding and Guiding the Professional Development of Teachers. Boston, MA: Allyn and Bacon, 1992.

[25] R. Fessler, "Dynamics of Teacher Career Stages," in Professional Development in Education, 1995.

[26] R. W. Lent, S. D. Brown, and G. Hackett, "Toward a Unifying Social Cognitive Theory of Career and Academic Interest, Choice, and Performance," Journal of Vocational Behavior. 1994, doi: 10.1006/jvbe.1994.1027.

[27] R. W. Lent and S. D. Brown, "Social Cognitive Approach to Career Development: An Overview," Career Development Quarterly. 1996, doi: 10.1002/j.2161-0045.1996.tb00448.x.

[28] D. M. Kagan, "Professional Growth Among Preservice and Beginning Teachers," Review of Educational Research, 1992, doi: 10.3102/00346543062002129.

[29] C. K. Waites, "The Professional Life-Cycles and Professional Development of Adult Teachers of English to Speakers of Other Languages (TESOL), a PhD dissertation, The Unversity of New South Wales, 1999.

[30] D. J. Smith and R. P. Sanche, "Interns' Personally Expressed Concerns: A Need to Extend the Fuller Model?," Action in Teacher Education, Vol. 15, No. 1, pp. 36-41, 1993, doi: 10.1080/01626620.1993.10463151.

[31] S. Rolls and H. Plauborg, "Teachers' Career Trajectories: An Examination of Research," Teacher Career Trajectories and Work Lives, pp. 9-28, 2009, doi: 10.1007/978-90-481-2358-2_2.

[32] M. Huberman, "The Professional Life Cycle of Teachers.," Teachers College Record, 1989.

[33] G. Hackett, N. Betz, J. Casas, and I. Rocha-Singh, "Gender, Ethnicity, and Social Cognitive Factors Predicting the Academic Achievement of Students in Engineering.," Journal of Counseling Psychology., Vol. 39, No. 4, pp. 527 538, 1992, doi: 10.1037/0022-0167.39.4.527.

[34] G. E. Hall and S. M. Hord, Implementing Change: Patterns, Principles, and Potholes. Boston, MA: Allyn and Bacon, 2006. 
[35] C. K. Reeves and R. Kazelskis, "Concerns of Preservice and Inservice Teachers," Journal of Educational Research, Vol. 78, No. 5, pp. 267-271, May 1985, doi: $10.1080 / 00220671.1985 .10885614$

[36] F. F. Fuller, "A Conceptual Framework for a Personalized Teacher Education Program," Theory into Practice, Vol. 13, No. 2, pp. 112-122, 1974, doi: 10.1080/0040584740954249 8 .

[37] C. K. Reeves and R. Kazelskis, "The Journal of Educational Research Concerns of Preservice and Inservice Teachers Concerns of Preservice and Inservice Teachers," Journal of Educational Research, 1985, doi: 10.1080/00220671.1985. 10885614

[38] P. F. Conway and C. M. Clark, "The Journey Inward and Outward: A Re-examination of Fuller's Concerns-based Model of Teacher Development," Teaching and Teacher Education, 2003, doi: 10.1016/S0742-051X(03)00046-5.

[39] R. N. Marso and F. L. Pigge, "The Influence of Preservice Training and Teaching Experience upon Attitude and Concerns about Teaching," Teaching and Teacher Education, Vol. 5, No. 1, pp. 33-41, 1989, doi: 10.1016/0742-051X(89)90017-6.

[40] F. L. Pigge and R. N. Marso, "A Seven-Year Longitudinal Multi-Factor Assessment of Teaching Concerns Development through Preparation and Early Years of Teaching," Teaching and Teacher Education, Vol. 13, No. 2, pp. 225-235, 1997, doi: 10.1016/S0742-051X(96)00014-5.

[41] P. Miksza and M. H. Berg, "A Longitudinal Study of Preservice Music Teacher Development: Application and Advancement of the Fuller and Bown Teacher-Concerns Model," Journal of Research in Music Education, Vol. 61, No. 1, pp. 44-62, 2013, doi: 10.1177/0022429412473606.

[42] A. M. Woods and S. K. Lynn, "One Physical Educator's Career Cycle: Strong Start, Great Run, Approaching Finish," Research Quarterly for Exercise and Sport, Vol. 85, No. 1, pp. 68-80, 2014, doi: 10.1080/02701367.2013.872218.

[43] L. Sheridan, "AA Passion and Enthusiasm to Bring out the Best in All': Regional Candidate Teacher Motivations," Australian Journal of Teacher Education, 2019, doi: 10.14221/ajte.2019v44n12.5.

[44] L. Y. A. Kremer-Hayon and R. Fessler, "The Inner World Of School Principals: Reflections On Career Life Stages", Perspective, Vol. 38, No. 1, pp. 35-45, 1992.

[45] R. Clemson-Ingram and R. Fessler, "Innovative Programs for Teacher Leadership," Action in Teacher Education, Vol. 19, No. 3, pp. 95-106, 1997, doi: $10.1080 / 01626620.1997 .10462882$.

[46] S. K. Lynn, “The Winding Path: Understanding the Career Cycle of Teachers," The Clearing House: A Journal of Educational Strategies, Issues and Ideas, Vol. 75, No. 4, pp. 179-182, 2002, doi: 10.1080/00098650209604926.

[47] M. Marušić and B. Bodroža, "Career Cycle of General and Special School Teachers in Serbia," Psihologija, Vol. 48, No. 2, pp. 165-181, 2015, doi: 10.2298/PSI1502165M.

[48] Z. Leehu and M. Ditza, "Teachers' Professional Development, Emotional Experiences and Burnout," International Journal of Advanced Educational Research, Vol. 2, No. 4, 2017, doi: 10.22606/jaer.2017.24009.
[49] K. Leithwood, A. Harris, and D. Hopkins, "Seven Strong Claims about Successful School Leadership," School Leadership and Management. 2008, doi: 10.1080/13632430701800060.

[50] N. E. Betz and G. Hackett, "Career Self-efficacy Theory: Back to the Future," Journal of Career Assessment, 2006, doi: $10.1177 / 1069072705281347$.

[51] R. W. Lent, S. D. Brown, and G. Hackett, "Contextual supports and barriers to career choice: A social cognitive analysis.," Journal of Counseling Psychology., 2000, doi: 10.1037//0022-0167.47.1.36.

[52] J. Swanson and P. Gore, "Advances in Vocational Psychology Theory and Research," in Handbook of Counseling Psychology, S. D. Brown and R. W. Lent, Eds. Hoboken, NJ: John Wiley \& Sons Inc, 2000, pp. 233-269.

[53] R. W. Lent and S. D. Brown, "Social Cognitive Career Theory and Subjective Well-being in the Context of Work," Journal of Career Assessment, 2008, doi: $10.1177 / 1069072707305769$.

[54] A. Bandura, Social Foundations of Thought and Action: A Social Cognitive Theory. Englewood Cliffs, NJ: Prentice-Hall, 1986.

[55] M. M. Gibbons and L. D. Borders, "Prospective First-Generation College Students: A Social-Cognitive Perspective," Career Development Quarterly, 2010, doi: 10.1002/j.2161-0045.2010.tb00186.x.

[56] N. E. Betz and G. Hackett, "Applications of Self-Efficacy Theory to Understanding Career Choice Behavior," J. Soc. Clin. Psychol., 1986, doi: 10.1521/jscp.1986.4.3.279.

[57] R. W. Lent and S. D. Brown, "Integrating Person and Situation Perspectives on Work Satisfaction: A Social-Cognitive View," Journal of Vocational Behavior., 2006, doi: 10.1016/j.jvb.2006.02.006.

[58] A. Bandura, "Comments on the Crusade against the Causal Efficacy of Human Thought," Journal of Behavior Therapy and Experimental Psychiatry, Vol. 26, pp. 179-190, 1995.

[59] A. Bandura, "Observational Learning," in Encyclopedia of Learning and Memory, L. Squire, Ed. New York, NY: Macmillan, 1992.

[60] A. Bandura, Self-efficacy: The Exercise of Control. New York, NY: Worth Publishers, 1997.

[61] M. Gagné and E. L. Deci, "Self-determination Theory and Work Motivation," Journal of Organizational Behavior, 2005, doi: 10.1002/job.322.

[62] A. Bandura, "Self-efficacy Conception of Anxiety," Anxiety Research, Vol. 1, pp. 77-98, 1988.

[63] R. Schwarzer, J. Mueller, and E. Greenglass, “Assessment of Perceived General Self-efficacy on the Internet: Data Collection in Cyberspace," Anxiety, Stress Coping, 1999, doi: 10.1080/10615809908248327.

[64] R. J. Burke, E. R. Greenglass, and R. Schwarzer, "Predicting Teacher Burnout over Time: Effects of Work Stress, Social Support, and Self-doubts on Burnout and Its Consequences," Anxiety, Stress Coping, 1996, doi: 10.1080/1061580960824 9406.

[65] A. Bandura, "Regulation of Cognitive Processes through 
Perceived Self-Efficacy," Developmental Psychology, Vol. 25, pp. 729-735, 1989.

[66] G. Hackett and N. E. Betz, "The Relationship of Career-Related Self-Efficacy Expectations to Perceived Career Options in College Women and Men," Journal of Counseling Psychology., 1981.

[67] L. M. Dos Santos, "Recruitment and Retention of International School Teachers in Remote Archipelagic Countries: The Fiji Experience," Education Sciences, Vol. 9 , No. 2, pp. 1-16, 2019, doi: 10.3390/educsci9020132.

[68] L. M. Dos Santos, "Engineering Education as a Second Career: The Experience of Female Practising Engineers," Global Journal of Engineering Education, Vol. 21, No. 3, pp. 202-207, 2019.

[69] L. M. Dos Santos, "Career Decision of Recent First-Generation Postsecondary Graduates at a Metropolitan Region in Canada: A Social Cognitive Career Theory Approach," Alberta Journal of Educational Research, Vol. 64, No. 2, pp. 141-152, 2018.

[70] R. G. Cinamon and Y. Rich, "Reducing Teachers' Work-Family Conflict," Journal of Career Development, Vol. 32, No. 1, pp. 91-103, 2005, doi: $10.1177 / 0894845305277044$.

[71] R. D. Duffy and R. W. Lent, "Test of a Social Cognitive Model of Work Satisfaction in Teachers," Journal of Vocational Behavior., Vol. 75, No. 2, pp. 212-223, 2009, doi: 10.1016/j.jvb.2009.06.001.

[72] B. McLennan, P. McIlveen, and H. N. Perera, "Pre-service Teachers' Self-Efficacy Mediates the Relationship between Career Adaptability and Career Optimism," Teaching and Teacher Education, Vol. 63, pp. 176-185, 2017, doi: 10.1016/j.tate.2016.12.022.

[73] L. M. Dos Santos, "The Relationship between Personal Beliefs and Teaching Practice of ESL Teachers at an Asian Community Centre in Vancouver: A Qualitative Research in Progress," Alberta Journal of Educational Research, 2017.

[74] A. Academies and I. Conference, "Academy of Entrepreneurship," Vol. 17, No. 1, 2011.

[75] K. Cruickshank, "Towards Diversity in Teacher Education: Teacher Preparation of Immigrant Teachers," European Journal of Teacher Education, Vol. 27, No. 2, pp. 125-138, 2004, doi: 10.1080/0261976042000223006.

[76] H. M. G. Watt and P. W. Richardson, "Motivational Factors Influencing Teaching as a Career Choice: Development and Validation of the FIT-choice Scale," Journal of Experimental Education, 2007, doi: 10.3200/JEXE.75.3.16 7-202.

[77] M. A. Flores and C. Day, "Contexts Which Shape and Reshape New Teachers' Identities: A Multi-Perspective Study," Teaching and Teacher Education, 2006, doi: 10.1016/j.tate.2005.09.002.

[78] R. D. Fantilli and D. E. McDougall, "A Study of Novice Teachers: Challenges and Supports in the First Years," Teaching and Teacher Education, 2009, doi: 10.1016/j.tate.2009.02.021.

[79] S. Marion, 'Understanding Pre-Service Teachers' Experience in a Multi-Modal Teaching Methods Course: A
Constructive-Developmental Perspective," 2004.

[80] M. K. Bendixen-Noe and S. S. Redick, "Teacher Development Theory: A Comparison between Traditional-Aged and Nontraditional-Aged Beginning Secondary Teachers," Action in Teacher Education, 1995, doi: 10.1080/01626620.1995.10463230.

[81] W. L. Rutherford and G. Hall, "Concerns of Teachers: Revisiting the Original Theory after Twenty Years," in American Educational Research Association (AERA) Conference, 1990.

[82] J. L. Watzke, "Longitudinal Research on Beginning Teacher Development: Complexity as a Challenge to Concerns-Based Stage Theory," Teaching and Teacher Education, Vol. 23, No. 1, pp. 106-122, 2007, doi: 10.1016/j.tate.2006.04.001.

[83] R. V. Bullough and J. G. Knowles, "Becoming a teacher: Struggles of a second-career beginning teacher," International Journal of Qualitative Studies in Education., 1990, doi: 10.1080/0951839900030201.

[84] E. Sharplin, "Bringing Them in: The Experiences of Imported and Overseas-Qualified Teachers," Australian Journal of Education., Vol. 53, No. 2, pp. 192-206, 2009, doi: 10.1177/000494410905300207.

[85] Datta Roy and S. Lavery, "Experiences of Overseas Trained Teachers Seeking Public School Positions in Western Australia and South Australia," Issues Educational Research, Vol. 27, No. 4, pp. 720-735, 2017.

[86] H. Markus and P. Nurius, "Possible selves.," American Psychologist, 1986, doi: 10.1037//0003-066x.41.9.954.

[87] M. Whitty, "Possible Selves: An Exploration of the Utility of a Narrative Approach," Identity, 2002, doi: 10.1207/s1532706xid0203_02.

[88] R. Sunley and R. Locke, "Exploring UK Secondary Teachers' Professional Values: An Overview of the Literature since 2000," Educational Research, 2010, doi: $10.1080 / 00131881.2010 .524751$.

[89] A. J. Martin and M. Dowson, "Interpersonal Relationships, Motivation, Engagement, and Achievement," Review of Educational Research, 2009.

[90] L. Thomas and C. Beauchamp, "Learning to Live Well as Teachers in a Changing World: Insights into Developing a Professional Identity in Teacher Education," Journal of Educational Thought, 2007.

[91] C. Beauchamp and L. Thomas, "Understanding teacher Identity: An Overview of Issues in the Literature and Implications for Teacher Education," Cambridge Journal of Education, 2009, doi: 10.1080/03057640902902252.

[92] H. M. G. Watt et al., "Motivations for Choosing Teaching as a Career: An International Comparison Using the FIT-Choice Scale," Teaching and Teacher Education, 2012, doi: 10.1016/j.tate.2012.03.003.

[93] K. M. Zeichner and K. Teitelbaum, "Personalized and Inquiry-Oriented Teacher Education: An Analysis of Two Approaches to the Development of Curriculum for Field-Based Experiences," Journal of Education for Teaching, 1982, doi: 10.1080/0260747820080201. 
[94] K. A. Leithwood, "The principal's role in teacher development," in Teacher Development and Educational Change, 2014.

[95] R. D. Gardner, "Should I Stay or Should I Go? Factors That Influence the Retention, Turnover, and Attrition Of K-12 Music Teachers in the United States," Arts Education Policy Review, 2010, doi: 10.1080/10632910903458896.

[96] M. Buchmann, "Role over Person: Morality and Authenticity in Teaching.," Teachers College Record, 1986.

[97] L. M. Howes and J. Goodman-Delahunty, “Teachers' Career Decisions: Perspectives on Choosing Teaching Careers, and on Staying or Leaving," Issues Educational Research, 2015.

[98] S. M. Kardos, S. M. Johnson, H. G. Peske, D. Kauffman, and E. Liu, "Counting on Colleagues: New Teachers Encounter the Professional Cultures of Their Schools," Educational Administration Quarterly, 2001, doi: 10.1177/00131610121 969316.

[99] P. W. Richardson and H. M. G. Watt†, "Who Chooses Teaching and Why? Profiling Characteristics and Motivations across Three Australian Universities," Asia-Pacific Journal of Teacher Education, 2006, doi: $10.1080 / 13598660500480290$.

[100] P. W. Richardson and H. M. G. Watt, "Current and Future Directions in Teacher Motivation Research," Advances in Motivation and Achievement, 2010, doi: 10.1108/S0749-7423(2010)000016B008.

[101] J. Buchanan, "Where are they now? Ex-teachers tell their life-work stories," Issues Educational Research, 2009.

[102] H. Cooper and K. M. Davey, "Teaching for Life? Midlife Narratives from Female Classroom Teachers Who Considered Leaving the Profession," British Journal of Guidance \& Counselling, 2011, doi: 10.1080/03069885.20 10.531386 .

[103] R. R. Henke, L. Zahn, and C. D. Carroll, "Attrition of New Teachers among Recent College Graduates: Comparing Occupational Stability among 1992-93 Graduates Who Taught and Those Who Worked In Other Occupations," Stat. Anal. Rep. / National Center for Education Statistics,
2001.

[104] P. Roberts, "Staffing an Empty Schoolhouse: Attracting and Retaining Teachers in Rural, Remote and Isolated Communities," 2004.

[105] A. A. Summers, R. J. Murnane, J. D. Singer, J. B. Willet, J. J. Kemple, and R. J. Olsen, "Who Will Teach? Policies That Matter," Journal of Policy Analysis and Management, 1992, doi: $10.2307 / 3324973$.

[106] J. Draper, H. Fraser, and W. Taylor, "Teachers' Careers: Accident or Design?," Teacher Development., 1998, doi: $10.1080 / 13664539800200059$.

[107] G. D. Borman and N. Maritza Dowling, "Teacher Attrition and Retention: A Meta-analytic and Narrative Review of the Research," Review of Educational Research, 2008, doi: $10.3102 / 0034654308321455$.

[108]C. R. Rinke, "Finding Their Way on: Career Decision-Making Processes of Urban Science Teachers," Science Education, 2009, doi: 10.1002/sce.20339.

[109] J. D. Singer, “Are Special Educators' Career Paths Special? Results from a 13-Year Longitudinal Study," Exceptional Children, Vol. 59, No. 3, pp. 262-279, 1992, doi: $10.1177 / 001440299305900309$.

[110]E. Taylor and J. Tyler, "The Effect of Evaluation on Performance: Evidence from Longitudinal Student Achievement Data of Mid-Career Teachers. NBER Working Paper No. 16877.," National Bureau of Economic Research, 2011, doi: 10.3386/w16877.

[111]C. Day and Q. Gu, "Variations in the Conditions for Teachers' Professional Learning and Development: Sustaining Commitment and Effectiveness over a Career," Oxford Review of Education, Vol. 33, No. 4, pp. 423-443, 2007, doi: 10.1080/03054980701450746.

[112] V. Korhonen and S. Törmä, "Engagement with a Teaching Career - How a Group of Finnish University Teachers Experience Teacher Identity and Professional Growth," Journal of Further and Higher Education, Vol. 40, No. 1, pp. 65-82, 2016, doi: 10.1080/0309877X.2014.895301. 